\title{
THE EFFECTIVENESS OF USING SCRABBLE AND BINGO GAME TECHNIQUE TOWARD STUDENTS' VOCABULARY MASTERY AT THE TENTH GRADE OF SMA N 2 METRO ACADEMIC YEAR 2013/2014
}

\author{
by \\ Ahmad Rosidi, Eva Falianti \\ English Education Study Program, Teacher Training and Education Faculty, \\ Muhammadiyah University of Metro \\ e-mail: ahmad.sugyu@gmail.com
}

\begin{abstract}
Vocabulary mastery is the activity to enrich the vocabulary, they master the vocabulary in order to be able to master four language skills. The problem formulation of this research are; (1) Is there any difference influence of using Scrabble and Bingo Game Technique toward Students' Vocabulary Mastery at The Tenth Grade of SMA N 2 Metro Academic Year 2013/3014? (2) Which one is more effective between Scrabble and Bingo Game Technique toward Students' Vocabulary Mastery at The Tenth Grade of SMA N 2 Metro Academic Year 2013/3014 ?, The object of this research are; (1) To know whether there is any difference Influence of using Scrabble and Bingo Game Technique toward Students' Vocabulary Mastery at The Tenth Grade of SMA N 2 Metro Academic Year 2013/3014, (2) To know which one is more effective between Scrabble and Bingo Game Technique toward Students' Vocabulary Mastery at The Tenth Grade of SMA N 2 Metro Academic Year 2013/3014. This research is Quantitative research. Research design that will be used in this research is true experimental design (pretest posttest control group design).. The population of this research is the students' of SMA N 2 Metro Academic Year 2013/2014 that consist of 660 students. The sample is 60 students. As the sample, 30 as experimental class and 30 as control class. In taking sample, the researcher used the cluster stratified random sampling. The data collecting tehniques the researcher used try-out, pre-test, treatment and post-test. The data analyzing tehniques, the researcher used normality test, homogenity test and hypothesis test. The differences of both the tehnique are Scrabble Game can make the students feel enjoy, creative and have a challenge and Bingo Game gives the students opportunity to identify the word interestingly. Based on the data analysis, the researcher uses $t_{-}$test formula. The researcher got the result of $t_{\text {observed }}=3,69$ and $t_{\text {table }}$ is 2.00. it means that $t_{\text {observed }}>t_{\text {table. }}$. And the criterion of $t_{\text {test }}$ is $H_{a}$ accepted if $t_{\text {observed }}>t_{\text {table }}$. So, there is any difference Influence of using Scrabble and Bingo Game Technique toward Students' Vocabulary Mastery at The Tenth Grade of SMA N 2 Metro academic year 2013/2014.
\end{abstract}

Key Words: Scrabble Game, Bingo Game, Vocabulary Mastery. 


\section{INTRODUCTION}

The most important thing is students have to acquire English that involves four language skills; namely listening, speaking, reading and writing. But, being able to master those skills, the students need vocabulary. McCarthy (1990: 30) states that no matter how well the students learn grammar, or how successful the sound of the languages are mastered, without words communication can not occur in any meaningful way. Many students get difficulty to express their idea in English, because their vocabulary is still limited. Ideally, students should master vocabulary well to support four language skills in English such as; listening, speaking, reading, and writing. The difficulty to express their idea becomes a problem that influences the students to learn English.

Based on pre survey in SMAN 2 Metro, the researcher found some students' problem in English lesson at the tenth grade. The students consist of 30 students. There are $41 \%$ students did not passed the passing grade, so only $59 \%$ students passed the passing grade. It means that the students' vocabulary mastery is still limited.

In this research, the researcher wants to know which one more effective of the instructional media toward vocabulary mastery. Among the instructional media, game is an interesting media which is used. Hadfield (1996: 3) states that a game is an activity with rules, a goal and an element of fun. Games can be used as one of the educational techniques in learning English. The game that used by the researcher are Scrabble and Bingo Game. Scrabble game has good effect to increase students' vocabulary mastery. Scrabble train the students to have good concentration and carefulness when they arrange letter chips to be a good word. The students have good motivation in learning English and students not bored, they feel interested, they not realize that they still learn, they have fun. In the same boat with Scrabble game, Bingo game also kind of word game. Conceptually, Scrabble and Bingo has same concept in applying in the 
classroom. It can train the students to be more concentration, carefulness, build their motivation and interested for them.

In this research the researcher wants to know which one is more effective between Scrabble and Bingo Game toward students' vocabulary mastery.

\section{THEORETICAL FRAMEWORK}

There are some literature overviews which related to this research. The first previous research was conducted by Putra (2012) entitled Improving Students' Vocabulary Mastery Through Crossword Puzzle Game at The Tenth Grade Students of SMK Mathla'ul Anwar Cibuah.

The ssecond previous research was conducted by Gita (2012) entitled Increasing Vocabulary Mastery Through Semantic Mapping to The Sixth Grade Students of Elementary School No. 27 Palembang.

The third previous research overview was conducted by Oliviana (2011) entitled The Comparison Towards Students' Vocabulary Mastery Between Using Jigsaw and TGT Technique for The Seventh Students in Junior High School State One of
Batanghari Academic Year 2011/2012.

Warner \& Brown (2005: 47) Scrabble is a proprietary board game, which involves the building of words for point scores, for two or more players (or teams). Besides Holden (2008: 16) states that scrabble is thought of as a game in which luck plays a significant part in determining whether you have good or bad letters on your rack. Scrabble can be used in developing problemsolving skills and is motivating for students. The advantages of Scrabble Game are Scrabble enhances memory skills, increases vocabulary, improves spelling and heightens strategic thinking.

The steps of play Scrabble are 1) Each player draws seven tiles and places them on his rack. 2) Examine the letters to be a good meaningfull words. 3) A player completes a turn by counting and announcing the score. 4) Play continues until all tiles have been drawn and one of the players has used all of the letters in his rack or until all possible plays have been made. 
Lo \& Tseng (2011: 1) state that Bingo is a popular and easy synchronous game without limitation of number of players. Usually bingo game is designed to facilitate learning mathematical skill of fraction. But today bingo can be a media in learning English. In learning English, bingo can be a word game that often used to improve students' vocabulary mastery. The advantages of Bingo Game are able to improve the students' vocabulary mastery, concentration, coordination, and stimulus.

The steps of play Bingo are 1) Create the Bingo card by drawing 5 vertical lines and 5 horizontal lines, 2) fill the Bingo card using the words from the list of vocabulary, 3) When a student gets a row either horizontally, vertically, or diagonally, they may say "BINGO" and to be the winner.

Vocabulary is one of the components in English which become the main basis of other skills they are listening, speaking, reading, and writing. Hornby (2000: 1331) states that vocabulary is the total number of words in a language. Besides
Mccarthy et al (2010: 1) state that vocabulary is all about word. All the words known to a person or used in a particular book, subject. A list of words with their meanings, especially one that accompanies a text book in a foreign language. Vocabulary is a compilation of words or phrases in foreign language which commonly arranged orderly and defined the meaning based on people's needs. Vocabulary is one of the language aspects which should be learnt. Learning vocabulary is important because people able to speak, listen, and write well when they have to know vocabulary first.

\section{METHOD}

The approach that used in this research is Quantitative approach. The design of this research is true experimental research. The type of this research is pre-test and post-test control group. The design can be presented as follows:

Table 3.1 Pre-test Post-test Control Group Design

\begin{tabular}{|l|c|c|c|}
\hline Class & Pretest & Treatment & Posttest \\
\hline $\begin{array}{l}\text { Experimental } \\
\text { Experim }\end{array}$ & $\mathrm{T}-1$ & $\mathrm{X}_{1}$ & $\mathrm{~T}-2$ \\
\hline$(\mathrm{M})(\mathrm{R})$ Control & $\mathrm{T}-1$ & $\mathrm{X}_{2}$ & $\mathrm{~T}-2$ \\
\hline
\end{tabular}

Accepted by Karwono (1992:77) 
Note:

$\mathrm{R}$ : Randomisasi

$\mathrm{M}$ : Matching

$\mathrm{X}_{1}$ : Treatment using Scrabble Game

$\mathrm{X}_{1}$ : Treatment using Bingo Game

T-1 : Pre-Test

T-2 : Post-test

There are three variables in this research, they are Y (students' vocabulary mastery) as dependent variable, $X_{1}$ (Scrabble game) and $X_{2}$ (Bingo game) as independent variables.

Then, the population of the research is students of SMA N 2 Metro academic year 2013/2014. The are twenty two classes, the average class consist of 30 students. So the total number of population is 660 students. In this research the researcher take two classes from all of the population of students at SMA N 2 Metro Academic Year 2013/2014 as the sample. Therefore, the researcher uses cluster stratified random sampling, and the class which consist of 30 students. Below the steps done by the researcher:

1. Write classes in piece of paper.

2. The papers is rolled and then put into the glass.

3. Then, the glass is shaken until getting rolling of paper out.
4. The first roll of paper will be the subject of the research as experimental class.

5. The second roll of paper will be the subject of the research as control class.

In this research the researcher used content validity. The researcher uses content validity because the test is used based on the content of learning material that is in curriculum and it is reasonable because the test involves the material learned.

The formula of validity is:

$\mathrm{rxy}=$

$\frac{\mathrm{n} \square \mathrm{X} . \mathrm{Y}-(\square \mathrm{X})(\square \mathrm{Y})}{\sqrt{\left\{\mathrm{n} \square \mathrm{X}^{2}(\square \mathrm{X})^{2}\right\}\left\{\mathrm{n} \cdot \square \mathrm{Y}^{2}(\square \mathrm{Y})^{2}\right\}}}$

Note:

$\mathrm{r}_{\mathrm{xy}}=$ Coefficient correlation Pearson

Product-Moment

$\mathrm{n}=$ Number of the Students

$\square=$ Sum

$\mathrm{X}=$ The score items of the test

$\mathrm{Y}=$ The total items score of the test $\mathrm{X}^{2}=$ Deviation $\mathrm{X}$

$\mathrm{Y}^{2}=$ Deviation $\mathrm{Y}$

To find the reliability test the researcher uses Spearman Brown (Split Half Technique). The formula as follow:

$\mathrm{r}_{11}=\frac{2 x r_{x y}}{\left(1+r_{x y}\right)}$

Adopted by Sugiyono (2013: 131) 
Note:

$\mathrm{r}_{11}=$ Reliability of instrument

$\mathrm{r}_{\mathrm{xy}}=$ Coefficient correlation Pearson Product-Moment

Then the result of $r_{11}$ will be consulted to the criteria of reliability as follow:

Reliability coefficient

1. A very high reliability ranges from 0.81 up to 1.00

2. A high reliability ranges from 0.61 up to 0.80

3. Average reliability ranges from 0.21 up to 0.60

4. A very low reliability rages from 0.00 up to 0.20

The result of realibity in tryout test is $\mathrm{r}_{11}=0,90$, so the reliabity of instrument is very high realiability. In means that the instrument can be used in this research.

After giving the test and finding the result of the test, student's score pre test and post test will be taken by using normality test, homogeneity test, and hypothesis test.

The purpose of normality test is to know whether data distribution is normal or not. The formula that can be used is as follow: $\square^{2}$ hit $\square \square_{i \square}^{k} \frac{\left(\tilde{\left.O_{i} \quad E_{1}\right)^{2}}\right.}{E_{1}}$

Adopted by Ahmad (2011:31)

The criteria of testing

Reject Ho if $=\square^{2}$ hit $\square \square^{2}$ daf

Where $\square_{\text {daf }}^{2} \square^{2}(\mathrm{I}-\alpha),(\mathrm{K}-3)$

Homogeneity is a measurement

which can be used to determine data variation. The formula of

homogeneity test is as follow:

$\mathrm{F}_{\text {ratio }}=\frac{\text { the bigest variance }}{\text { the smallest variance }}$

The criteria of testing:

Reject $\mathrm{H}_{\mathrm{o}}$ if $\mathrm{F}_{\text {hit }} \geq \mathrm{F}_{\text {daf }}$

Accept $\mathrm{H}_{0}$ if $\mathrm{F}_{\text {hit }}<\mathrm{F}_{\text {daf }}$

Where $\mathrm{F}_{\text {daf }}=\mathrm{F}_{1 / 2} \alpha\left(n_{1}-1, n_{2-} 1\right), \square$ get from $10 \%$ and $2 \%$

When the sample comes from the population which is distributed normally and homogeneously, the test will be continued to the hypothesis test. Some steps of hypothesis test as follow:

1. Formula of hypothesis

$\mathrm{H}_{\mathrm{o}}=\mu 1=\mu 2$ (there is no influence)

$\mathrm{H}_{\mathrm{a}}=\mu 1 \neq \mu 2$ (there is any influence)

2. Statistic formula

If $\sigma 1=\sigma 2=\sigma$, and $\sigma$ is unknown, the statistic is : 
$T_{\text {ratio }}=\frac{X_{1}-X_{2}}{\sqrt[s_{8}]{\frac{1}{n_{1}}+\frac{1}{n_{2}}}}$

Where:

$S_{g}^{2}=\frac{\left(n_{1}-1\right) S_{1}^{2}+\left(n_{2}-1\right) S_{2}^{2}}{n_{1}+n_{2}-2}$

The testing criteria received $\mathrm{H}_{\mathrm{o}}$ if $\mathrm{t}_{\text {table }}<\mathrm{t}_{\text {ratio }}<\mathrm{t}_{\text {table }}$

The criteria are:

1. $\mathrm{H}_{\mathrm{o}}$ : is accepted if t-ratio is equal or lower t-table (the hypothesis proposed is not proved)

2. $\mathrm{H}_{\mathrm{a}}$ : is accepted if t-ratio is equal or higher than t-table (the hypothesis proposed is proved)

\section{DISCUSSION}

In this research, the researcher want to know which one is more effective between Scrabble and Bingo Game toward students' vocabulary mastery. From the data in pre test, the result of normality test is distributed normally. It is showed from the experimental class $\mathrm{X}_{\text {ratio }}^{2}(2,72) \leq$ $\mathrm{X}_{\mathrm{df}}^{2}(7,81)$ and $(11,3)$.

From the result of calculation, it is obtained that $\mathrm{x}^{2}$ hit is lower than $\mathrm{x}^{2}{ }_{\text {daf }}$ in both of significance level $5 \%(\alpha=$ $0.05)$ and1\% $(\alpha=0.01)$. So the hypothesis $\mathrm{H}_{\mathrm{a}}$ is accepted. It means that both samples in this research have normal distribution.

From the counting data of homogenity, the result shows the data is homogenous. By dividing the highest variance with the smallest variance from standart deviation. The data homogeneity of the test accepted $\mathrm{H}_{\mathrm{a}}$ if $\mathrm{F}_{\text {ratio }}<\mathrm{F}_{\mathrm{df}}$ for the significance level 5\% $(\alpha=0.05)$ and also the significance level $1 \%(\alpha=$ $0.01) . \mathrm{F}_{\text {ratio }}(1.10)<\mathrm{F}_{\mathrm{df}}(1,85)$ and $(2,41)$.

Based on the data analyzing, it found that $\mathrm{t}_{\text {hit }}=3,69, \alpha=1 \%$ the $\mathrm{t}_{\text {table }}=2,66$ and $\alpha=5 \%$ the $t_{\text {table }}=2,00$. So, Ho is rejected and Ha is accepted. It means that Scrabble Game is more effective than Bingo Game toward students'.

\section{CONCLUSION}

Based on the objectives and result of the research, the researcher draws the conclusion as follow:

5.1.1 There is any different influence of using Scrabble and Bingo Game Technique toward students' vocabulary mastery at the tenth grade of SMA N 2 Metro academic year 2013/2014. In Scrabble Game 
the students are more creative, and they enjoy when play the game. So it is more effective for the students to enrich their vocabulary and identify the word classes easily because they have fun in playing the game. But in Bingo Game the students are confused by the list of Vocabulary, they needs more concentration to examine the words. It makes the students still difficult to enrich their vocabulary but it is effective to identify the word classes accurately. It is proven by the result of pre-test and post-test. After the researcher applied both Game for treatment, the result showed the improvement of students' vocabulary mastery. The differences of both technique are: Scrabble Game is interesting for the students. The students are demanding to work with many letters which should be examine to be a good meaningful word. It can be a challenged for them tried to found as many as possible words to be the winner. So, the students will be motivated to found many words and make them creative. Meanwhile, Bingo Game is good educational game especially to improve students' vocabulary mastery. But in applying the game, the students often face difficulty, the students were not interested to list of vocabularies, it makes them confused. Besides, it is new design game for them and they are not familiar with the game.

\subsubsection{Scrabble Game is more} effective than Bingo Game to improve students' vocabulary mastery. Based on the previous result of the calculation, the result showed that $\mathrm{H}_{\mathrm{a}}$ is accepted and $\mathrm{H}_{\mathrm{O}}$ is rejected. The hypothesis can be accpeted because $t_{\text {hit }}$ is 3,69 and $t_{\text {table }}$ is 2,66 at the significance level 0,01 and $t_{\text {table }}$ is 2,00 at the significance level 0,05. Also from the result of average score of the students who taught by Scrabble Game is 60,1 in pretest and 74,7 in posttest. 
Meanwhile, the result of average score of the students who taught by Bingo Game is 57,8 in pretest and 68,2 in posttest. It means that there is a significant different of influence between Scrabble and Bingo Game technique toward students' vocabulary mastery at the tenth grade of SMA N 2 Metro. The result score of the research showed that the students who taught by Scrabble Game is higher than Bingo Game. So it is clear that the hypothesis $H_{a}$ is accepted. Based on the result and discussion above, the researcher conclude that Scrabble Game is more effective than Bingo Game technique toward students' vocabulary mastery at the tenth grade of SMAN 2 Metro academic year 2013/2014.

\section{SUGGESTION}

After conducting the research, the researcher would like to give some suggestions addressed to readers as follows:
5.2.1 In order to be able to improve the students' vocabulary mastery, it is suggested to English teacher to find the various topics of vocabulary which can invite the students to be more creative during improving the vocabulary. Because there are many vocabularies that should be mastered by the students to be able to master English well.

5.2.2 In order to improve the students' vocabulary mastery, the researcher suggests to English teacher to use interesting technique or use interesting media in learning vocabulary. So, the students will be enjoy and interested in learning vocabulary in the class. By applying interesting media such as Scrabble Game, the students will have high motivation to increase their vocabulary. The students will be creative in playing the game to arrange the letters to be a good meaningful word. 
5.2.3 In order to be able to improve the students' vocabulary mastery, it is suggested for the next researcher to find out the research if taking the same hope to make the students become creative, enjoy, and interested during learning vocabulary in order to increase students' vocabulary mastery.

\section{REFERENCES}

Ahmad, J. 2011. Statistik. Metro

City: UMMetro Press.

Gita, A. (2012). Increasing Vocabulary Mastery Through Semantic Mapping to The Sixth Grade Students of Elementary School No. 27 palembang. Published in Palembang.

Hadfield, J. (1996). Advanced Communication Game. England: Addison wesley longman.

Holden, S. (2008). The Scrabble Player's Handbook. England: Hasbro inc.

Karwono. (1992). Jurnal Teknologi Pembalajaran Teori dan Penelitian: IKIP Malang.

Lo, J. \& Tseng, F. (2011). A Bingo Game for English Vocabulary
Learning. Departement of Information Management. Chung Hua University. Hsinchu, Taiwan: World academic publishing.

Mccarthy, M. et al. (2010). Vocabulary Matrix Understanding, Learning, Teaching. United kingdom: Heinle cengage learning EMEA.

Oliviana, C. (2011). The Comparison Toward Students' Vocabulary Mastery Between Using Jigsaw and TGT Technique for The Seventh Students in Junior High School State One of Batang Hari in Academic Year 2011/2012. Published in Muhammadiyah University of Metro.

Putra, Y. A. (2012). Improving Students' Vocabulary Mastery Through Crossword Puzzle Game at The Tenth Grade Students' of SMK Mathla'ul Anwar Cibuah Academic Year 2011/2012. Published in STKIP Setia Budhi Rangkasbitung.

Sugiyono. (2013). Metode Penelitian Pendidikan Pendekatan Kuantitatif, Kualitatif, dan $R \& D$. Bandung: Alfabeta

Warner, H., \& Brown, T. P. (2005). Scrabble Unscrabbled: Adult ESL Students' Perception of Scrabble as a Classroom Learning Tool. No. 2, Vol. 20. New Zealand. 